\title{
Boekbespreking
}

\section{Opleiden van medisch specialisten}

Cate ThJ ten, Bleker OP, Büller HA, Scherpbier AJJA. Opleiden van medisch specialisten. Achtergronden en praktijk. Reeks Medicus en Management, deel 8. Houten: Bohn Stafleu Van Loghum; 2003. 251 pagina's. ISBN 90313 41851. Prijs: 29.50 Euro.

'Opleiden van medisch specialisten' is vooral een praktisch boek voor iedereen die betrokken is bij de opleiding van medisch specialisten. De vier auteurs zijn erkende vernieuwers van het medisch onderwijs en pleitbezorgers voor een vernieuwing van de specialistenopleiding. $\mathrm{Zij}$ zijn er in dit boek in geslaagd om gevestigde en nieuwe onderwijsprincipes te vertalen in de dagelijkse praktijk van de opleiding. Het boek is opgebouwd uit zes delen.

Na de inleiding over de veranderingen van de opleiding in het kader van 'De arts van straks' en 'De zorg van morgen' volgt een hoofdstuk over het onderwijskundig perspectief. In dit hoofdstuk worden principes uit de cognitieve psychologie en de onderwijskunde, die voor de specialistenopleiding van belang zijn, beschreven.

In de volgende drie kernhoofdstukken komen veel praktische aspecten van de assistent-in-opleiding, de opleider en het effectief opleiden en toetsen aan de orde. Ook ervaren opleiders zullen in deze hoofdstukken nuttige beschrijvingen en adviezen vinden voor een gestructureerd opleidingsprogramma, een kritisch opleidingsklimaat, een zelfstandig lerende assistent, een deskundig opleidingsteam en een goede opleider.

In de paragrafen over de organisatie van de opleiding worden gebruikelijke leermomenten, zoals het ochtendrapport met elementen van evidence based medicine en critical appraisal van de literatuur, bedside teaching met aandacht voor het rolmodel van de opleiders, de complicatiebespreking en de attitude die daarbij hoort, genuanceerd besproken. De verschillende onderdelen worden daarbij doorgaans afgesloten met een praktische, samenvattende tabel.
Het hoofdstuk over het beoordelen en toetsen van assistenten volgt de huidige inzichten hierover en biedt uitstekende voorbeelden, zoals de inmiddels goed gevalideerde 'Korte Klinische Beoordelingsexercitie', de Amerikaanse 'miniCEX', aanwijzingen voor de beoordeling van competenties en de introductie van een portfolio.

Het laatste hoofdstuk bevat beknopte informatie over de regelgeving van de specialistenopleiding in Nederland en in Europa. Het boek wordt afgesloten met een handige lijst van elektronische informatiebronnen over het medisch onderwijs en over de specialistenopleiding.

In dit Nederlandse boek wordt wel erg zwaar geleund op de Amerikaanse en de Engelse literatuur over de opleiding van specialisten. Het meest uitgesproken is dat het geval in de paragraaf over de arts-assistent met problemen. Problemen door werkbelasting en slaapgebrek zijn typisch voor de Angelsaksische opleiding en niet erg waarschijnlijk binnen onze werktijdenregeling. Het is zelfs de vraag of Nederland zich niet internationaal uit de markt heeft geprezen met de gemiddelde leerwerkweek van 48 uur voor assistenten-in-opleiding. Daarentegen worden de problemen van deeltijdopleiding en zwangerschap tijdens de opleiding wel erg makkelijk op het bord van de opleider gelegd.

In de inleiding van het boek wordt terecht geconcludeerd dat het opleiden van specialisten nog beter, nog efficiënter en nog leuker kan worden en dat daarvoor deskundigheid, tijd en geld nodig zijn. Dit boek draagt ongetwijfeld op een zeer praktische manier bij aan de vergroting van de deskundigheid van opleiders van medisch specialisten. De beperking van het boek ligt in het ontbreken van een visie over de ontwikkeling van specialismen en de daarbij passende opleiding. Het antwoord op de vraag waar tijd en geld gezocht moeten worden voor de nog betere specialistenopleiding in Nederland wordt tevergeefs in het boek gezocht.

In de infobox aan het eind van het boek wordt een lijst van aanbevolen handboeken voor de opleider gegeven. Daarin ontbreekt ge- 
heel ten onrechte 'Time to heal' van de internistopleider Kenneth M. Ludmerer. Visie en maatschappelijke inbedding van de specialistenopleiding staan daarin centraal, en daarom vormt dat boek de ideale achtergrondliteratuur voor het praktisch opleiden van specialisten.

Laat duidelijk zijn dat ik 'Opleiden van medisch specialisten' met toenemend enthousiasme heb gelezen. In een ongetwijfeld volgende, tweede druk kunnen nog enkele schoonheidsfoutjes worden hersteld. William Osler heeft veel betekenis gehad voor de opleiding in de Verenigde Staten, maar de definitie van het opleidingsprogramma (blz.18) is afkomstig uit het rapport van Abraham Flexner uit 1910. Mijn positieve waardering voor het boek zou toenemen wanneer in deze tweede druk een visionair hoofdstuk zou worden toegevoegd. Ook de huidige editie van 'Opleiden van medisch specialisten' verdient zeker een plaats in de aanbevolen bibliotheek van iedere opleider.

H.F.P. Hillen

Decaan Faculteit der Geneeskunde,

Universiteit Maastricht 